\title{
Effects of rapeseed meal fiber content on phosphorus and calcium digestibility in growing pigs fed diets without or with microbial phytase
}

\author{
M. Bournazel ${ }^{1,2}$, M. Lessire ${ }^{1}$, M. J. Duclos ${ }^{1}$, M. Magnin $^{2}$, N. Même ${ }^{1}$, C. Peyronnet ${ }^{3}$, \\ E. Recoules ${ }^{1}$, A. Quinsac ${ }^{4}$, E. Labussière ${ }^{5}$ and A. Narcy ${ }^{1+}$ \\ ${ }^{1}$ URA, INRA, 37380 Nouzilly, France; ${ }^{2}$ MiXscience, Centre d'affaires Odyssée, ZAC Cicé Blossac, 35172 Bruz, France; ${ }^{3}$ Terres Univia, 11 rue Monceau, 75008 Paris, \\ France; ${ }^{4}$ Terres Inovia, 11 rue Monge, Parc Industriel, 33600 Pessac, France; ${ }^{5}$ PEGASE, Agrocampus Ouest, INRA, Domaine de la Prise, 35590 Saint-Gilles, France
}

(Received 4 November 2016; Accepted 18 April 2017; First published online 29 June 2017)

The optimization of dietary phosphorus (P) and calcium (Ca) supply requires a better understanding of the effect of dietary fiber content of co-products on the digestive utilization of minerals. This study was designed to evaluate the effects of dietary fiber content from 00-rapeseed meal (RSM) on P and Ca digestibility throughout the gastrointestinal tract in growing pigs fed diets without or with microbial phytase. In total, 48 castrated male pigs (initial BW $=36.1 \pm 0.4 \mathrm{~kg}$ ) were housed in metabolic crates for 29 days. After an 8-day adaptation period, pigs were allocated to one of the eight treatments. The impact of dietary fiber was modulated by adding whole RSM (WRSM), dehulled RSM (dRSM) or dRSM supplemented with $4.5 \%$ or $9.0 \%$ rapeseed hulls (dRSMh1 and dRSMh2). Diets contained 0 or 500 phytase unit of microbial phytase per $\mathrm{kg}$. From day 14 to day 23, feces and urine were collected separately to determine apparent total tract digestibility (ATTD) and apparent retention (AR) of $P$ and Ca. At the end of the experiment, femurs and digestive contents were sampled. No effect of variables of interest was observed on growth performance. Microbial phytase increased ATTD and AR of $P(\mathrm{P}<0.001)$ but the $P$ equivalency with the wRSM diet was lower than expected. Moreover, stomach inorganic $P$ (iP) solubility was improved by microbial phytase $(\mathrm{P}<0.001)$. The ATTD of Ca was not affected by microbial phytase which increased AR of $C a$ and femur characteristics $(\mathrm{P}<0.05)$. lleal recovery of $P$ was not affected by microbial phytase but cecal recovery was considerably reduced by microbial phytase $(\mathrm{P}<0.001)$. The decrease in digesta $\mathrm{pH}$ between the distal ileum and cecum $(7.6 \mathrm{v} .5 .9)$ enhanced the solubility of $\mathrm{i} P$ and may have improved its absorption, as supported by the negative relationship between soluble $\mathrm{i} P$ and $\mathrm{pH}$ $\left(\mathrm{R}^{2}=0.40, \mathrm{P}<0.001\right.$ without microbial phytase and $\mathrm{R}^{2}=0.24, \mathrm{P}=0.026$ with microbial phytase). The inclusion of hulls improved the solubility of $\mathrm{i} P(\mathrm{P}<0.05)$. In conclusion, dehulling does not largely increase nutrient digestibility although dRSM seems to improve the efficacy of microbial phytase in releasing phosphate in the stomach. Moreover, dietary fiber may affect solubilization process in the cecum which potentiates the effect of microbial phytase on $P$ digestibility.

Keywords: calcium, dietary fiber, microbial phytase, phosphorus, rapeseed meal

\section{Implications}

Dehulling is a relevant process to reduce the fiber content of rapeseed meal and to concentrate protein and energy fraction. However it seems to have a low impact on phosphorus ( $\mathrm{P})$ and calcium (Ca) digestibility, whereas it improves phosphorus equivalency of microbial phytase. This implies that phosphorus equivalencies need to be adapted according to the type of rapeseed meal used and to the fiber level.

\footnotetext{
${ }^{\dagger}$ E-mail: agnes.narcy@inra.fr
}

\section{Introduction}

The inclusion of co-products, such as 00-rapeseed meal (RSM), in pig diets increased over the last decade because of its higher availability and its low glucosinolates and erucic acid content. Nevertheless, RSM is characterized by a relatively high dietary fiber and phytate content $(0.50 \%)$ which are considered as anti-nutritional factors. Procedures, such as dehulling the seed, are of great interest to reduce the dietary fiber fraction which is mainly located in the hulls (Carré et al., 2015). However, the impact of dietary fiber of RSM on $\mathrm{P}$ digestibility remains unknown whereas dietary 
provision of $\mathrm{P}$ for pigs is still an environmental and economic challenge. Previous studies focused on measuring the apparent, true or standardized digestibility of $\mathrm{P}$ in diets with RSM, but did not investigate the specific effect of RSM fiber on digestive process (Adhikari et al., 2015; Shi et al., 2015).

According to the literature, the effects of dietary fiber on $P$ digestibility in pigs are not consistent and depend strongly on the source and the inclusion level (Metzler and Monsenthin, 2008). Dietary fiber can affect digestive process in the upper gastrointestinal tract because of their physico-chemical properties (Jha and Berrosco, 2015), and consequently phytate degradation by microbial phytase (Kemme et al., 2006; Dersjant-Li et al., 2015). The decrease of the $\mathrm{pH}$ between the terminal ileum and the cecum (from 7.0 to 6.0) due to microbial breakdown of fiber may improve the solubility of minerals, thereby increasing their absorption (Scholz-Arhens and Schrezenmeir, 2007). In addition, dietary fiber could affect Ca digestibility (Nortey et al., 2008) modifying in this way $\mathrm{Ca}$ and $\mathrm{P}$ balance and consequently bone mineralization. In this regard, we hypothesized that (1) dehulling the seed could improve nutrient digestibility by reducing the fiber matrix effect, (2) the hull content could lead to fermentations in the lower intestine enhancing mineral solubility and (3) the response to microbial phytase might be affected by RSM inclusion.

Therefore, the aim of the present study was to investigate the effects of dietary fiber content of RSM on $\mathrm{P}$ and $\mathrm{Ca}$ digestibility as well as on bone mineralization in growing pigs fed diets without or with microbial phytase, and to evaluate their impacts on $\mathrm{P}$ and $\mathrm{Ca}$ solubility in relation to the $\mathrm{pH}$, and their recovery throughout the gastrointestinal tract.

\section{Material and methods}

The experimental protocol was approved by the Regional Ethics Committee on animal experimentation (Rennes, France) and the French Ministry of Higher Education and Research (Paris, France; authorization: 02402.03).

\section{Raw materials and experimental diets}

The RSM used was a 00-rapeseed meal. From a single batch of seed, whole RSM and dehulled RSM were processed at the CREOL pilot plant (Pessac, France; Supplementary Table S1). The dehulling of seed was performed before oil extraction and hulls were collected. Extraction was done using hexane.

The eight experimental diets were based on $67 \%$ corn and $10 \%$ soybean meal. Phosphorus and Ca were marginally deficient in diets without microbial phytase according to the French recommendations for $40 \mathrm{~kg}$ pigs (Jondreville and Dourmad, 2005). The dietary fiber content of the diets was modulated by adding RSM. The first diet (wRSM) included $15 \%$ whole RSM to adjust the protein concentration to $15 \%$ (Table 1). The second diet (dRSM) included $10.5 \%$ dehulled RSM to provide similar amounts of protein to wRSM. The third and fourth diets (dRSMh1 and dRSMh2, respectively) included $10.5 \% \mathrm{dRSM}$ and $4.5 \%$ or $9.0 \%$ hulls, respectively.
Diets were supplemented with 0 or 500 phytase units (FTU) microbial phytase per $\mathrm{kg}$ (Natuphos ${ }^{\circledR}$ from Aspergillus niger, BASF SE, Ludwigshafen, Germany). The level of apparent digestible P (Sauvant et al., 2004) was fixed at $0.16 \%$ in diets without microbial phytase and at $0.24 \%$ in diets supplemented with microbial phytase, in accordance with the French recommendations, considering an equivalency of $0.8 \mathrm{~g} / \mathrm{kg}$ of apparent digestible P with $500 \mathrm{FTU}$ microbial phytase/kg (Jondreville and Dourmad, 2005). The Ca: apparent digestible $P$ ratio was adjusted to 2.6 using calcium carbonate. Titanium dioxide $\left(\mathrm{TiO}_{2}, 0.30 \%\right)$ was added as an indigestible marker. The diets were offered to pigs as pellets.

\section{Animals and experimental procedures}

The experiment included 48 castrated male Piétrain $\times$ (Landrace $\times$ Large White) pigs weighing $36.1 \pm 0.4 \mathrm{~kg}$. Animals were housed in crates equipped with a slatted floor with a tray underneath that allowed separation of urines and feces collection. From day 0 to day 7 , the pigs received a standard diet covering all their nutrient requirements (9.7 MJ net energy and $18 \%(\mathrm{CP})$. At day 8 , pigs were assigned to one of the eight experimental diets (six pigs/diet) in a complete randomized block design (six blocks of eight treatments). The pigs were offered an equal quantity of feed daily distributed in two equivalent meals corresponding to $4 \%$ of their BW. Daily feed intake was recorded individually during the experimental period. Collection period started at day 14 and ended at day 23 after an overnight fast to ensure the emptying of the intestine. Feces were collected at meal times (twice a day) and pooled by pig. At the end of the collection period, feces were mixed thoroughly with water, sampled, weighed and freeze-dried. Acidified urine ( $1 \%$ of the total, with $3 \mathrm{ml}$ of $10 \%$ sulfuric acid/l of urine) was also collected individually each day and stored at $-20^{\circ} \mathrm{C}$. Pigs were weighed at day 0 , day 8 , day 14 and day 23. Room temperature was maintained at $20 \pm 1^{\circ} \mathrm{C}$. At the end of the experiment, individual pigs received half of their daily feed allowance in the morning and the other half $2 \mathrm{~h} 30 \mathrm{~min}$ before slaughter. They were anesthetized by electroimmobilization and slaughtered by exsanguination. The viscera were immediately removed and samples of digesta were collected from stomach, duodenum, jejunum (from the end of duodenum to the beginning of ileum), proximal ileum ( $1 \mathrm{~m}$ before distal ileum), distal ileum $(80 \mathrm{~cm}$ anterior to the ileocecal valve), cecum and middle of the colon, homogenized and stored at $-80^{\circ} \mathrm{C}$. A sample of digesta from the cecum and the distal ileum was freeze-dried for $48 \mathrm{~h}$ and then ground. Femurs were also collected and stored at $-20^{\circ} \mathrm{C}$.

\section{Analyses}

All samples were analyzed in duplicate. The crude fiber content was measured with the Weende method (NF V03 040), and NDF, ADF and ADL were obtained according to Van Soest et al. (1991). Soluble and insoluble fibers were determined according to Prosky method (AOAC 991.42 and 993.19). The initial $\mathrm{pH}$ and the buffering capacity to $\mathrm{pH} 3$ were measured according to Lawlor et al. (2005). Dry matter of diets, feces and digestive content of ileum and cecum, and $\mathrm{P}, \mathrm{Ca}$ and $\mathrm{TiO}_{2}$ 
analysis were performed as previously explained by Rousseau et al. (2016). Phytase activity was measured according to Engelen et al. (1994). Levels of Ca and P content were measured in diets, feces and urine to determine apparent total tract digestibility (ATTD) and apparent retention (AR). Levels of $\mathrm{P}, \mathrm{Ca}$ and $\mathrm{TiO}_{2}$ were measured in diets and digesta to determine $\mathrm{Ca}$ and $\mathrm{P}$ recovery. The soluble $\mathrm{Ca}$ and inorganic $\mathrm{P}$ (iP) levels were determined in the stomach and cecal supernatant fractions, after centrifuging the samples at $23000 \mathrm{~g}$ for $10 \mathrm{~min}$ at $4^{\circ} \mathrm{C}$. Inorganic $P$ was analyzed using a kit (Kit Phosphore UV 61571; bioMérieux, 69280 Marcy l'Etoile, France). Nitrogen (NF EN ISO 5983-2) and fat (NF ISO 6492) were determined in diets. The $\mathrm{pH}$ was measured on all digestive contents with a pH meter (InLab Solid Pro-ISM with SevenGo Duo ${ }^{\mathrm{TM}}$ SG23; Mettler Toledo, Greifensee, Switzerland). Right femurs were broken and then defatted using ether, dried at $103^{\circ} \mathrm{C}$ for $18 \mathrm{~h}$ and finally ashed in a muffle furnace at $600^{\circ} \mathrm{C}$ for $16 \mathrm{~h}$. The left femurs were analyzed using computed tomography (Siemens Emotion Duo, Erlangen, Germany). Bone densitometry (BD) was determined using $\mathrm{X}$-ray absorbance: mineral density was proportional to grayscale value in Hounsfield units (HU), from 250 to $1500 \mathrm{HU}$.

\section{Calculations and statistical analysis}

lleal and cecal recovery were calculated using the following equation:

$$
\text { Recovery }=\left(X_{\text {diet }} / X_{\text {digesta }}\right) \times\left(\mathrm{TiO}_{2 \text { digesta }} / \mathrm{TiO}_{2 \text { diet }}\right)
$$

Where $X$ is the amount of $\mathrm{P}$ or $\mathrm{Ca}$ in the diet or in the digesta $(\mathrm{mg} / \mathrm{g} \mathrm{DM})$ and $\mathrm{TiO}_{2}$ the amount of $\mathrm{TiO}_{2}$ in the diet or in the digesta (mg/g DM).

The $P$ equivalency values were calculated using the ATTD of $P$ and the dietary $P$ content following the method of Kerr et al. (2010), and the analyzed values of phytase activity.

All data were analyzed using the MIXED procedure of SAS (SAS Institute Inc., Cary, NC, USA) as appropriate for a randomized complete block design. Crates location was the blocking factor and pigs were the experimental unit. The model included diets as fixed effect and block as random effect. Orthogonal polynomial contrasts were used to separate treatment means. Contrasts were chosen to study the effects of (1) microbial phytase (linear (Lin), mean of diets without phytase $v$. mean of diets with phytase), (2) dehulled rapeseed without microbial phytase (Lin, wRSM - v. dRSM -) and (3) with microbial phytase (Lin, wRSM + v. dRSM +), (4) the hull content without microbial phytase (Lin, quadratic (Qua), dRSM - v. dRSMh1 v. dRSMh2 -) and (5) with microbial phytase (Lin, Qua, $\mathrm{dRSM}+\quad v \cdot \mathrm{dRSMh1}+\quad v \cdot \mathrm{dRSMh2}+$ ). Differences were considered significant at $P<0.05$ and to have a tendency at $0.05 \leqslant P<0.10$. Relationships between the $\mathrm{pH}$ and the mineral solubility in the stomach and in the cecum were quantified using regression analysis with the REG procedure of SAS. The relation between the $i \mathrm{P}$ solubility in the stomach and $\mathrm{BD}$ was estimated using a quadratic regression model as well as broken-line and curvilinear-plateau regression models. Estimates were obtained using REG and NLIN procedures of SAS (Supplementary Figure S1).

\section{Results}

\section{Nutritional values of experimental diets}

The $\mathrm{P}$ and $\mathrm{Ca}$ concentrations analyzed in the experimental diets were in accordance with the expected values (Table 1). Analyzed phytase activity was $650,450,870$ and $630 \mathrm{FTU} / \mathrm{kg}$ in $\mathrm{WRSM}+, \mathrm{dRSM}+, \mathrm{dRSMh1}+$ and $\mathrm{dRSMh2}+$ diets, respectively, and less than the detection limit of $100 \mathrm{FTU} / \mathrm{kg}$ in the diets without microbial phytase. As expected, NDF, ADF, $A D L$, insoluble and soluble fiber contents decreased when including $\mathrm{dRSM}(7.8 \%, 2.9 \%,<0.5 \%, 1.2 \%$ and $10.7 \%$, respectively). The dRSMh1 diet contained almost the same level of fibers as wRSM while dRSMh2 presented the highest level of fibers $(13.1 \%, 7.3 \%, 2.8 \%, 1.8 \%$ and $15.5 \%$, respectively).

\section{Growth performance and bone mineralization}

There was no significant effect of microbial phytase, dehulled seed and hull content on BW at day 8 , day 23 or on average daily gain between day 8 and day 23 (Table 2). The inclusion of hulls without microbial phytase influenced the feed conversion ratio (Qua; $P=0.037$ ) and the inclusion of hulls with microbial phytase increased the average daily feed intake $(P=0.017)$. Microbial phytase increased femur ash weight $(P<0.001)$ and content $(P=0.005)$, and bone density $(P<0.001)$.

\section{Phosphorus and calcium balance}

Microbial phytase decreased $P$ fecal excretion $(-25 \%$, $P<0.001$; Table 3), increased $P$ urinary excretion $(+30 \%$, $P=0.020)$, ATTD of $P(+18.4$ points; $P<0.001)$, AR of $P(+17.6$ points; $P<0.001)$, Ca fecal excretion $(+33 \%$, $P<0.001)$ and $A R$ of $\mathrm{Ca}(+6.7$ points; $P=0.011)$. With microbial phytase, the inclusion of hulls affected $P$ urinary excretion ( $+36 \%$; Qua, $P=0.040$ ). The $P$ equivalency values were $0.48,0.69,0.88$ and $0.84 \mathrm{~g}$ of apparent digestible $\mathrm{P} / \mathrm{kg}$ of diet for WRSM, dRSM, dRSMh1 and dRSMh2, respectively.

$\mathrm{pH}$ of digestive contents and stomach solubility, ileal recovery and cecal solubility and recovery of phosphorus and calcium Microbial phytase increased duodenum $(P=0.031)$ and colon pH ( $P=0.017$; Table 4$)$ except in the duodenum of pigs fed the wRSM diet. The dRSM- diet increased jejunum $(P=0.006)$ and cecum pH $(P<0.001)$ compared with WRSM - . Without microbial phytase, the inclusion of hulls decreased cecum $\mathrm{pH}$ (Lin, $P=0.006$ ). Total and soluble $\mathrm{P}$ and $\mathrm{Ca}$ in the stomach and cecum are presented in the Supplementary Table S2. Microbial phytase increased iP solubility in the stomach $(P<0.001$; Table 4$)$ and decreased iP solubility $(P=0.008)$ and $P$ recovery in the cecum $(P<0.001)$. Without microbial phytase, the inclusion of hulls increased iP solubility (Lin and Qua, $P<0.001$ ) and recovery of Ca in the cecum (Lin, $P=0.017$ and Qua, $P=0.033$ ). With microbial phytase, the inclusion of hulls increased iP solubility (Lin, $P=0.026$ and Qua, $P=0.014$ ) and decreased Ca solubility (Lin, $P=0.001$ and Qua, $P=0.032$ ). 
Table 1 Ingredients and chemical composition of experimental diets (as-fed basis)

\begin{tabular}{|c|c|c|c|c|c|c|c|c|}
\hline & \multicolumn{2}{|c|}{ wRSM } & \multicolumn{2}{|c|}{$\mathrm{dRSM}$} & \multicolumn{2}{|c|}{ dRSMh1 } & \multicolumn{2}{|c|}{ dRSMh2 } \\
\hline & - & + & - & + & - & + & - & + \\
\hline \multicolumn{9}{|l|}{ Ingredients (\%) } \\
\hline Corn & 67.01 & 67.01 & 67.00 & 67.00 & 66.99 & 66.99 & 66.99 & 66.99 \\
\hline Soybean meal & 10.00 & 10.00 & 10.00 & 10.00 & 10.00 & 10.00 & 10.00 & 10.00 \\
\hline Rapeseed meal & 15.00 & 15.00 & - & - & - & - & - & - \\
\hline Dehulled rapeseed meal & - & - & 10.50 & 10.50 & 10.50 & 10.50 & 10.50 & 10.50 \\
\hline Rapeseed hulls & - & - & - & - & 4.50 & 4.50 & 9.00 & 9.00 \\
\hline Cornstarch & 5.78 & 5.24 & 9.99 & 9.45 & 5.73 & 5.28 & 1.43 & 0.90 \\
\hline Calcium carbonate & 0.45 & 0.99 & 0.56 & 1.10 & 0.44 & 0.98 & 0.33 & 0.86 \\
\hline Dicalcium phosphate & 0.40 & 0.40 & 0.40 & 0.40 & 0.40 & 0.40 & 0.40 & 0.40 \\
\hline Sodium chloride & 0.25 & 0.25 & 0.25 & 0.25 & 0.25 & 0.25 & 0.25 & 0.25 \\
\hline Titanium dioxide & 0.30 & 0.30 & 0.30 & 0.30 & 0.30 & 0.30 & 0.30 & 0.30 \\
\hline Sodium bicarbonate & 0.30 & 0.30 & 0.30 & 0.30 & 0.30 & 0.30 & 0.30 & 0.30 \\
\hline L-Lysine $\mathrm{HCl}$ & 0.36 & 0.36 & 0.44 & 0.44 & 0.40 & 0.36 & 0.36 & 0.36 \\
\hline DL-Methionine & 0.03 & 0.03 & 0.06 & 0.06 & 0.05 & 0.03 & 0.03 & 0.03 \\
\hline L-Threonine & 0.09 & 0.09 & 0.13 & 0.13 & 0.10 & 0.08 & 0.08 & 0.08 \\
\hline L-Tryptophan & 0.03 & 0.03 & 0.04 & 0.04 & 0.04 & 0.03 & 0.03 & 0.03 \\
\hline L-Valine & - & - & 0.03 & 0.03 & - & - & - & - \\
\hline \multicolumn{9}{|l|}{ Nutritional characteristics ${ }^{1}(\%)$} \\
\hline DM & 87.3 & 88.5 & 88.0 & 87.9 & 87.3 & 88.2 & 87.4 & 88.7 \\
\hline Phytase (FTU/kg) & $<100$ & 650 & $<100$ & 450 & $<100$ & 870 & $<100$ & 630 \\
\hline $\mathrm{Ca}$ & 0.44 & 0.62 & 0.40 & 0.58 & 0.44 & 0.58 & 0.42 & 0.60 \\
\hline Total P & 0.47 & 0.44 & 0.44 & 0.43 & 0.45 & 0.46 & 0.46 & 0.47 \\
\hline $\operatorname{dig} \mathrm{P}^{2}, 3$ & 0.16 & 0.24 & 0.16 & 0.24 & 0.16 & 0.24 & 0.16 & 0.24 \\
\hline Ca: digP & 2.8 & 2.6 & 2.6 & 2.5 & 2.8 & 2.4 & 2.7 & 2.5 \\
\hline Fat & 3.0 & 3.1 & 2.9 & 2.7 & 2.9 & 2.8 & 3.2 & 3.0 \\
\hline $\mathrm{CP}(\mathrm{N} \times 6.25)$ & 15.4 & 14.6 & 14.6 & 14.5 & 14.7 & 14.3 & 15.2 & 15.3 \\
\hline NDF & 10.5 & 10.5 & 7.8 & 7.8 & 10.0 & 10.0 & 13.1 & 13.1 \\
\hline ADF & 5.1 & 5.1 & 2.9 & 2.9 & 5.3 & 5.3 & 7.3 & 7.3 \\
\hline$A D L$ & 1.6 & 1.6 & $<0.5$ & $<0.5$ & 1.6 & 1.6 & 2.8 & 2.8 \\
\hline Soluble fiber & 1.7 & 1.7 & 1.2 & 1.2 & 1.3 & 1.3 & 1.8 & 1.8 \\
\hline Insoluble fiber & 13.1 & 13.1 & 10.7 & 10.7 & 12.7 & 12.7 & 15.5 & 15.5 \\
\hline Net energy (MJ/kg $\left.{ }^{2}\right)$ & 9.95 & 9.89 & 10.30 & 10.24 & 9.86 & 9.80 & 9.41 & 9.36 \\
\hline Initial pH & 6.9 & 7.0 & 7.1 & 7.0 & 7.0 & 6.9 & 6.9 & 6.9 \\
\hline BUF 3 & 147 & 158 & 123 & 153 & 124 & 165 & 122 & 162 \\
\hline
\end{tabular}

wRSM = whole rapeseed meal; dRSM = dehulled rapeseed meal; dRSMh1 = dehulled rapeseed meal with $4.5 \%$ rapeseed hulls; dRSMh2 = dehulled rapeseed meal with $9 \%$ rapeseed hulls $(-=$ without microbial phytase and $+=$ with $500 \mathrm{FTU} / \mathrm{kg}$ ); BUF = buffering capacity to $\mathrm{pH} 3$.

${ }^{1}$ Analyzed values (as described in 'Material and methods' section).

${ }^{2}$ Calculated values.

${ }^{3}$ Apparent digestible phosphorus (Sauvant et al., 2004).

\section{Regression analysis}

With microbial phytase, soluble iP was negatively correlated with the $\mathrm{pH}$ of the stomach content $\left(R^{2}=0.31, P=0.009\right.$; Figure 1a) but no effect was observed without microbial phytase. Soluble $\mathrm{Ca}$ was negatively correlated with the $\mathrm{pH}$ of the stomach content without microbial phytase $\left(R^{2}=0.53\right.$, $P<0.001$; Figure $1 \mathrm{~b})$ and with $\mathrm{MP}\left(R^{2}=0.85, P<0.001\right)$. Soluble $i \mathrm{P}$ in the cecum was negatively correlated with $\mathrm{pH}$ without $\left(R^{2}=0.40, P<0.001\right.$; Figure 2$)$ and with microbial phytase $\left(R^{2}=0.24, P=0.026\right)$.

\section{Discussion}

Using dRSM instead of wRSM or adding hulls did not affect the ATTD or AR of P and Ca. However, the P equivalency value was twofold lower with the wRSM diet than expected $(0.48$ v. $0.83 \mathrm{~g} / \mathrm{kg}$; Kerr et al., 2010). Moreover, the solubility of $i \mathrm{P}$ in the stomach tended to be enhanced with dehulled seeds in diets supplemented with microbial phytase. These results suggest that dehulling the seed enhances the action of microbial phytase which takes place mainly in the stomach. Phytate is distributed throughout the kernel in sub-cellular inclusions known as globoids (Singh, 2008). Removing hulls from the seed may reduce binding and physical entrapment of phytate, improving in this way the accessibility to the enzyme (Baye et al., 2015). This hypothesis is confirmed by the fact that the positive effect is remaining with the dRSMh1 + diet although it almost contains the same level of fibers as wRSM + . In addition, neither dehulled seeds nor the inclusion of hulls significantly affected 
Table 2 Growth performance and femurs characteristics in pigs fed experimental diets namely whole rapeseed meal (wRSM), dehulled RSM (dRSM) or dRSM supplemented with 4.5\% or 9.0\% rapeseed hulls (dRSMh1 and dRSMh2, respectively) ${ }^{1}$

\begin{tabular}{|c|c|c|c|c|c|c|c|c|c|c|c|c|c|c|c|c|}
\hline \multirow{4}{*}{$\frac{\frac{\text { Description }}{\text { MP suppl. }^{3}}}{\text { Diets }}$} & & & \multirow{2}{*}{\multicolumn{2}{|c|}{ dRSM }} & \multirow{2}{*}{\multicolumn{2}{|c|}{ dRSMh1 }} & \multirow{2}{*}{\multicolumn{2}{|c|}{ dRSMh2 }} & & \multicolumn{7}{|c|}{$P$ P-value ${ }^{2}$} \\
\hline & \multicolumn{2}{|c|}{ wRSM } & & & & & & & & \multirow{3}{*}{$\frac{\frac{\text { Effect of microbial phytase }}{1,3,5,7 \text { v. } 2,4,6,8}}{\text { Lin }}$} & \multicolumn{2}{|c|}{ Effect of dRSM } & \multicolumn{4}{|c|}{ Effect of hulls content } \\
\hline & \multirow{2}{*}{$\frac{-}{1}$} & \multirow{2}{*}{$\frac{+}{2}$} & \multirow{2}{*}{$\frac{-}{3}$} & \multirow{2}{*}{$\frac{+}{4}$} & \multirow{2}{*}{-} & \multirow{2}{*}{$\frac{+}{6}$} & \multirow{2}{*}{$\frac{-}{7}$} & \multirow{2}{*}{$\frac{+}{8}$} & \multirow[b]{2}{*}{ SEM } & & \multirow{2}{*}{$\frac{1 \mathrm{v} \cdot 3}{\operatorname{Lin}}$} & \multirow{2}{*}{$\frac{2 v .4}{\operatorname{Lin}}$} & \multicolumn{2}{|c|}{3 v. 5 v. 7} & \multicolumn{2}{|c|}{4 v. 6 v. 8} \\
\hline & & & & & & & & & & & & & Lin & Qua & Lin & Qua \\
\hline BW day $8(\mathrm{~kg})$ & 40.3 & 40.4 & 40.1 & 39.8 & 39.5 & 40.7 & 40.2 & 40.4 & 0.3 & 0.54 & 0.81 & 0.57 & 0.94 & 0.67 & 0.57 & 0.85 \\
\hline BW day $23(\mathrm{~kg})$ & 52.8 & 53.2 & 52.6 & 52.3 & 52.0 & 53.4 & 52.0 & 52.8 & 0.3 & 0.28 & 0.80 & 0.36 & 0.56 & 0.74 & 0.62 & 0.92 \\
\hline ADG (g/day) & 833 & 850 & 833 & 828 & 833 & 850 & 789 & 822 & 15 & 0.36 & 1.00 & 0.50 & 0.19 & 0.13 & 0.87 & 0.56 \\
\hline ADFI (kg/day) & 1.58 & 1.58 & 1.59 & 1.56 & 1.58 & 1.58 & 1.57 & 1.60 & 0.01 & 0.51 & 0.56 & 0.093 & 0.22 & 0.30 & 0.017 & 0.36 \\
\hline FCR & 1.87 & 1.88 & 1.93 & 1.89 & 1.85 & 1.88 & 2.02 & 1.97 & 0.03 & 0.76 & 0.39 & 0.86 & 0.20 & 0.037 & 0.31 & 0.20 \\
\hline \multicolumn{17}{|l|}{ Femurs characteristics } \\
\hline Dry weight (g) & 83.8 & 91.4 & 89.0 & 85.2 & 81.4 & 97.0 & 87.1 & 88.8 & 1.5 & 0.063 & 0.36 & 0.27 & 0.73 & 0.70 & 0.51 & 0.63 \\
\hline Ash weight (g) & 31.6 & 36.8 & 32.3 & 36.0 & 29.9 & 38.0 & 32.3 & 36.7 & 0.6 & $<0.001$ & 0.63 & 0.55 & 1.00 & 0.31 & 0.62 & 0.79 \\
\hline Ash $(\% \mathrm{DM})$ & 38.3 & 40.3 & 36.5 & 42.6 & 37.0 & 39.4 & 37.6 & 41.3 & 0.6 & 0.005 & 0.45 & 0.36 & 0.63 & 0.67 & 0.61 & 0.86 \\
\hline $\operatorname{BD}\left(\mathrm{cm}^{2}\right)$ & $\begin{array}{l}30.3 \\
6.40\end{array}$ & $\begin{array}{r}4.3 \\
8.44\end{array}$ & 6.93 & $\begin{array}{l}4.0 \\
7.75\end{array}$ & $\begin{array}{r}3.09 \\
5.99\end{array}$ & $\begin{array}{r}39.4 \\
8.50\end{array}$ & $\begin{aligned} & 3.0 \\
& 6.91\end{aligned}$ & $\begin{array}{c}41.3 \\
8.27\end{array}$ & 0.17 & $<0.001$ & 0.19 & 0.090 & 0.97 & 0.19 & 0.19 & 0.66 \\
\hline
\end{tabular}

$\mathrm{ADG}=$ average daily gain; $\mathrm{ADFI}=$ average daily feed intake; $\mathrm{FCR}=$ feed conversion ratio; $\mathrm{BD}=$ bone density: area greater than $250 \mathrm{HU}$; Lin = linear; Qua = quadratic.

$n=6$ pigs per diet.

${ }^{2}$ Contrast analysis: linear effect of microbial phytase; linear effect of dehulled rapeseed seed without and with microbial phytase; linear and quadratic effects of the inclusion of hulls without and with microbial phytase.

${ }^{3}$ Microbial phytase supplementation: $-=$ without microbial phytase and $+=$ with $500 \mathrm{FTU} / \mathrm{kg}$.

Table 3 Intake, fecal excretion, urinary excretion, apparent total tract digestibility (ATTD), apparent retention (AR) in pigs fed experimental diets namely whole rapeseed meal (wRSM), dehulled RSM (dRSM) or dRSM supplemented with $4.5 \%$ or $9.0 \%$ rapeseed hulls (dRSMh1 and dRSMh2, respectively) ${ }^{1}$

\begin{tabular}{|c|c|c|c|c|c|c|c|c|c|c|c|c|c|c|c|c|}
\hline \multirow{4}{*}{$\frac{\text { Description }}{\text { MP suppl. }^{3}}$} & & & \multirow{2}{*}{\multicolumn{2}{|c|}{ dRSM }} & \multirow{2}{*}{\multicolumn{2}{|c|}{ dRSMh1 }} & \multirow{2}{*}{\multicolumn{2}{|c|}{ dRSMh2 }} & & \multicolumn{7}{|c|}{$P$-value ${ }^{2}$} \\
\hline & \multicolumn{2}{|c|}{ wRSM } & & & & & & & & \multirow{3}{*}{$\frac{\frac{\text { Effect of microbial phytase }}{1,3,5,7 \text { v. } 2,4,6,8}}{\text { Lin }}$} & \multicolumn{2}{|c|}{ Effect of dRSM } & \multicolumn{4}{|c|}{ Effect of hulls content } \\
\hline & \multirow{2}{*}{$\frac{-}{1}$} & \multirow{2}{*}{$\frac{+}{2}$} & \multirow{2}{*}{-} & \multirow{2}{*}{$\frac{+}{4}$} & \multirow{2}{*}{-} & \multirow{2}{*}{$\frac{+}{6}$} & \multirow{2}{*}{$\frac{-}{7}$} & \multirow{2}{*}{$\frac{+}{8}$} & \multirow[b]{2}{*}{ SEM } & & \multirow{2}{*}{$\frac{1 \text { v. } 3}{\operatorname{Lin}}$} & \multirow{2}{*}{$\frac{2 \text { v. } 4}{\operatorname{Lin}}$} & \multicolumn{2}{|c|}{3 v. 5 v. 7} & \multicolumn{2}{|c|}{4 v. 6 v. 8} \\
\hline & & & & & & & & & & & & & Lin & Qua & Lin & Qua \\
\hline \multicolumn{17}{|l|}{ Phosphorus } \\
\hline Intake (g/day) & 7.10 & 6.84 & 6.70 & 6.58 & 6.92 & 6.98 & 6.99 & 7.19 & 0.03 & 0.011 & $<0.001$ & $<0.001$ & $<0.001$ & $<0.001$ & $<0.001$ & $<0.001$ \\
\hline Fecal excretion (g/day) & 5.01 & 3.90 & 4.94 & 3.62 & 5.25 & 3.78 & 5.26 & 3.99 & 0.11 & $<0.001$ & 0.76 & 0.19 & 0.14 & 0.37 & 0.087 & 0.12 \\
\hline Urinary excretion (g/day) & 0.09 & 0.13 & 0.11 & 0.11 & 0.10 & 0.11 & 0.10 & 0.15 & 0.01 & 0.020 & 0.25 & 0.56 & 0.78 & 0.97 & 0.069 & 0.040 \\
\hline ATTD (\% of intake) & 29.5 & 43.0 & 26.3 & 45.0 & 24.1 & 45.8 & 24.7 & 44.5 & 1.6 & $<0.001$ & 0.29 & 0.51 & 0.60 & 0.85 & 0.87 & 0.73 \\
\hline AR (\% of intake) & 28.2 & 39.8 & 24.5 & 43.2 & 22.5 & 43.8 & 23.0 & 42.0 & 1.5 & $<0.001$ & 0.25 & 0.29 & 0.65 & 0.87 & 0.70 & 0.58 \\
\hline \multicolumn{17}{|l|}{ Calcium } \\
\hline Intake (g/day) & 6.68 & 9.49 & 6.18 & 8.81 & 6.66 & 8.83 & 6.77 & 9.27 & 0.19 & $<0.001$ & $<0.001$ & $<0.001$ & $<0.001$ & $<0.001$ & $<0.001$ & $<0.001$ \\
\hline Fecal excretion (g/day) & 3.61 & 4.64 & 3.07 & 4.14 & 3.46 & 4.16 & 3.33 & 4.83 & 0.13 & $<0.001$ & 0.18 & 0.21 & 0.52 & 0.85 & 0.089 & 0.055 \\
\hline Urinary excretion (g/day) & 0.81 & 0.52 & 0.68 & 0.71 & 0.59 & 0.54 & 0.56 & 0.45 & 0.04 & 0.15 & 0.40 & 0.18 & 0.36 & 0.50 & 0.059 & 0.14 \\
\hline ATTD (\% of intake) & 50.3 & 51.2 & 50.4 & 53.1 & 48.1 & 52.9 & 50.9 & 50.6 & 0.9 & 0.28 & 0.98 & 0.59 & 0.89 & 0.59 & 0.50 & 0.48 \\
\hline AR (\% of intake) & 32.6 & 45.7 & 39.3 & 45.0 & 39.3 & 46.8 & 42.7 & 43.2 & 1.4 & 0.011 & 0.19 & 0.90 & 0.51 & 0.44 & 0.72 & 0.54 \\
\hline
\end{tabular}

Lin = linear; Qua = quadratic

${ }^{1} n=6$ pigs per diet.

${ }^{2}$ Contrast analysis: linear effect of microbial phytase; linear effect of dehulled rapeseed seed without and with microbial phytase; linear and quadratic effects of the inclusion of hulls without and with microbial phytase.

${ }^{3}$ Microbial phytase supplementation: $-=$ without microbial phytase and $+=$ with $500 \mathrm{FTU} / \mathrm{kg}$. 
Rapeseed fiber and mineral digestibility

Table 4 Phosphorus and calcium solubility in the stomach and the cecum, recovery in the ileum and cecum and pH of digesta in different segments of the digestive tract in pigs fed experimental diets namely whole rapeseed meal (WRSM), dehulled RSM (dRSM) or dRSM supplemented with $4.5 \%$ or $9.0 \%$ rapeseed hulls (dRSMh1 and dRSMh2, respectively, DM basis) ${ }^{1}$

\begin{tabular}{|c|c|c|c|c|c|c|c|c|c|c|c|c|c|c|c|c|}
\hline \multirow{4}{*}{$\begin{array}{l}\text { Description } \\
\text { MP suppl. } \\
\text { Diets }\end{array}$} & \multirow{2}{*}{\multicolumn{2}{|c|}{ wRSM }} & \multirow{2}{*}{\multicolumn{2}{|c|}{ dRSM }} & \multirow{2}{*}{\multicolumn{2}{|c|}{ dRSMh1 }} & \multirow{2}{*}{\multicolumn{2}{|c|}{$\mathrm{dRSMh2}$}} & & \multicolumn{7}{|c|}{$P$-value ${ }^{2}$} \\
\hline & & & & & & & & & & \multirow{3}{*}{$\begin{array}{c}\begin{array}{c}\text { Effect of microbial } \\
\text { phytase }\end{array} \\
1,3,5,7 \text { v. } 2,4,6,8 \\
\text { Lin }\end{array}$} & \multicolumn{2}{|c|}{ Effect of dRSM } & \multicolumn{4}{|c|}{ Effect of hulls content } \\
\hline & \multirow{2}{*}{$\frac{-}{1}$} & \multirow{2}{*}{$\frac{+}{2}$} & \multirow{2}{*}{-} & \multirow{2}{*}{$\frac{+}{4}$} & \multirow{2}{*}{-} & \multirow{2}{*}{$\frac{+}{6}$} & \multirow{2}{*}{-} & \multirow{2}{*}{$\frac{+}{8}$} & \multirow[b]{2}{*}{ SEM } & & \multirow{2}{*}{$\frac{1 \text { v. } 3}{\operatorname{Lin}}$} & \multirow{2}{*}{$\frac{2 \text { v. } 4}{\operatorname{Lin}}$} & \multicolumn{2}{|c|}{3 v. 5 v. 7} & \multicolumn{2}{|c|}{4 v. 6 v. 8} \\
\hline & & & & & & & & & & & & & Lin & Qua & $\operatorname{Lin}$ & Qua \\
\hline \multicolumn{17}{|l|}{$\begin{array}{l}\text { pH of digestive } \\
\text { content }\end{array}$} \\
\hline Stomach & 5.26 & 5.53 & 5.55 & 5.56 & 5.45 & 5.45 & 5.18 & 5.64 & 0.05 & 0.096 & 0.17 & 0.88 & 0.087 & 0.090 & 0.72 & 0.47 \\
\hline Duodenum & 5.79 & 5.69 & 5.77 & 6.02 & 5.61 & 6.09 & 5.48 & 6.03 & 0.07 & 0.031 & 0.94 & 0.20 & 0.22 & 0.31 & 0.94 & 0.92 \\
\hline Jejunum & 6.36 & 6.45 & 6.59 & 6.44 & 6.50 & 6.49 & 6.46 & 6.49 & 0.02 & 0.73 & 0.006 & 0.85 & 0.10 & 0.21 & 0.55 & 0.74 \\
\hline $\begin{array}{l}\text { Proximal } \\
\text { ileum }\end{array}$ & 7.36 & 7.49 & 7.53 & 7.20 & 7.65 & 7.44 & 7.41 & 7.28 & 0.05 & 0.19 & 0.41 & 0.16 & 0.58 & 0.33 & 0.69 & 0.81 \\
\hline Distal ileum & 7.52 & 7.79 & 7.57 & 7.44 & 7.63 & 7.68 & 7.60 & 7.50 & 0.05 & 0.80 & 0.77 & 0.062 & 0.89 & 0.99 & 0.72 & 0.73 \\
\hline Cecum & 5.75 & 6.05 & 6.14 & 5.93 & 6.03 & 5.97 & 5.84 & 5.85 & 0.03 & 0.84 & $<0.001$ & 0.28 & 0.006 & 0.010 & 0.45 & 0.29 \\
\hline Colon & 6.06 & 6.36 & 6.03 & 6.28 & 6.07 & 6.12 & 6.01 & 6.23 & 0.05 & 0.017 & 0.87 & 0.63 & 0.91 & 0.78 & 0.73 & 0.88 \\
\hline \multicolumn{17}{|c|}{$\begin{array}{l}\text { Inorganic phosphorus } \\
\text { solubility (\%) }\end{array}$} \\
\hline Stomach & 9.97 & 17.50 & 8.43 & 21.92 & 9.51 & 20.60 & 9.74 & 18.11 & 0.93 & $<0.001$ & 0.49 & 0.067 & 0.56 & 0.69 & 0.11 & 0.12 \\
\hline Cecum & 2.55 & 1.87 & 1.97 & 1.92 & 2.55 & 1.99 & 3.36 & 2.71 & 0.11 & 0.008 & 0.12 & 0.88 & $<0.001$ & $<0.001$ & 0.026 & 0.014 \\
\hline \multicolumn{17}{|c|}{ Calcium solubility (\%) } \\
\hline Stomach & 6.84 & 8.99 & 5.78 & 7.95 & 7.59 & 9.37 & 8.03 & 6.54 & 0.44 & 0.20 & 0.55 & 0.56 & 0.21 & 0.40 & 0.40 & 0.16 \\
\hline Cecum & 1.17 & 1.30 & 0.98 & 1.61 & 1.05 & 0.99 & 1.20 & 0.93 & 0.06 & 0.25 & 0.35 & 0.12 & 0.29 & 0.30 & 0.001 & 0.032 \\
\hline \multicolumn{17}{|c|}{ Phosphorus recovery } \\
\hline Ileum & 0.55 & 0.54 & 0.59 & 0.49 & 0.58 & 0.51 & 0.62 & 0.60 & 0.02 & 0.13 & 0.50 & 0.40 & 0.66 & 0.52 & 0.087 & 0.083 \\
\hline Cecum & 0.50 & 0.25 & 0.52 & 0.29 & 0.49 & 0.34 & 0.57 & 0.33 & 0.02 & $<0.001$ & 0.68 & 0.48 & 0.31 & 0.14 & 0.45 & 0.77 \\
\hline \multicolumn{17}{|c|}{ Calcium recovery } \\
\hline Ileum & 0.56 & 0.64 & 0.61 & 0.59 & 0.61 & 0.66 & 0.54 & 0.68 & 0.02 & 0.094 & 0.57 & 0.50 & 0.41 & 0.34 & 0.25 & 0.43 \\
\hline Cecum & 0.59 & 0.54 & 0.52 & 0.53 & 0.57 & 0.56 & 0.62 & 0.60 & 0.01 & 0.33 & 0.094 & 0.84 & 0.017 & 0.033 & 0.082 & 0.11 \\
\hline
\end{tabular}

Lin = linear; Qua = quadratic.

${ }^{1} n=6$ pigs per diet.

${ }^{2}$ Contrast analysis: linear effect of microbial phytase; linear effect of dehulled rapeseed seed without and with microbial phytase; linear and quadratic effects of the inclusion of hulls without and with microbial phytase.

${ }^{3}$ Microbial phytase supplementation: $-=$ without microbial phytase and $+=$ with $500 \mathrm{FTU} / \mathrm{kg}$.

the absorption of $\mathrm{P}$ and $\mathrm{Ca}$ in the small intestine. There is some evidence that fiber can modulate the absorption of minerals from the upper gastrointestinal tract (Metzler and Monsenthin, 2008). The estimated content in hemicelluloses fractions was increased by almost $20 \%$ between dRSM and wRSM or dRSMh2 diets. The ability of hemicelluloses to bind $\mathrm{Ca}$ is particularly high at neutral $\mathrm{pH}$, especially compared with lignin (Claye et al., 1998). The level of inclusion of hulls in the present experiment might have been too low to induce significant effects in the small intestine on mineral availability. The hull content of the diet did not affect the cecal recovery of $P$. Nevertheless, increasing the level of hulls reduced the $\mathrm{pH}$ of the cecal content $(6.14$ v. 5.84) in pigs fed diets without microbial phytase and slightly improved the solubility of iP in the cecal content. Fiber from hulls, although mostly insoluble, may have been fermented and thus lowered the $\mathrm{pH}$. The higher acidity produced through fermentation resulted in greater solubility and availability of P. Indeed, both soluble and insoluble dietary fiber can be degraded by intestinal bacteria, but insoluble fiber is less easily, rapidly and completely fermented than soluble fiber (Bach Knudsen and Hansen, 1991). The effects of fiber on mineral absorption in the hindgut are controversial. The source and the inclusion level of dietary fiber have a considerable effect on $\mathrm{P}$ absorption or secretion in the large intestine as a result of the different bacteria $P$ needs for fermentation (Metzler and Monsenthin, 2008). For instance, an increase in the cellulose content of the diet from $3 \%$ to $9 \%$ was reported to negatively affect the absorption of $P$ from the large intestine (Partridge, 1978b). In contrast, some studies using various types of fiber have suggested greater P absorption (Den Hartog et al., 1988; Heijnen and Beynen, 1998). The cecal recovery of Ca was higher when the inclusion level of hulls was increased (from 0.53 to 0.61 on average for $\mathrm{dRSM}$ and $\mathrm{dRSMh2}$, respectively). Moreover, although low, the solubility of Ca was reduced when the hull 

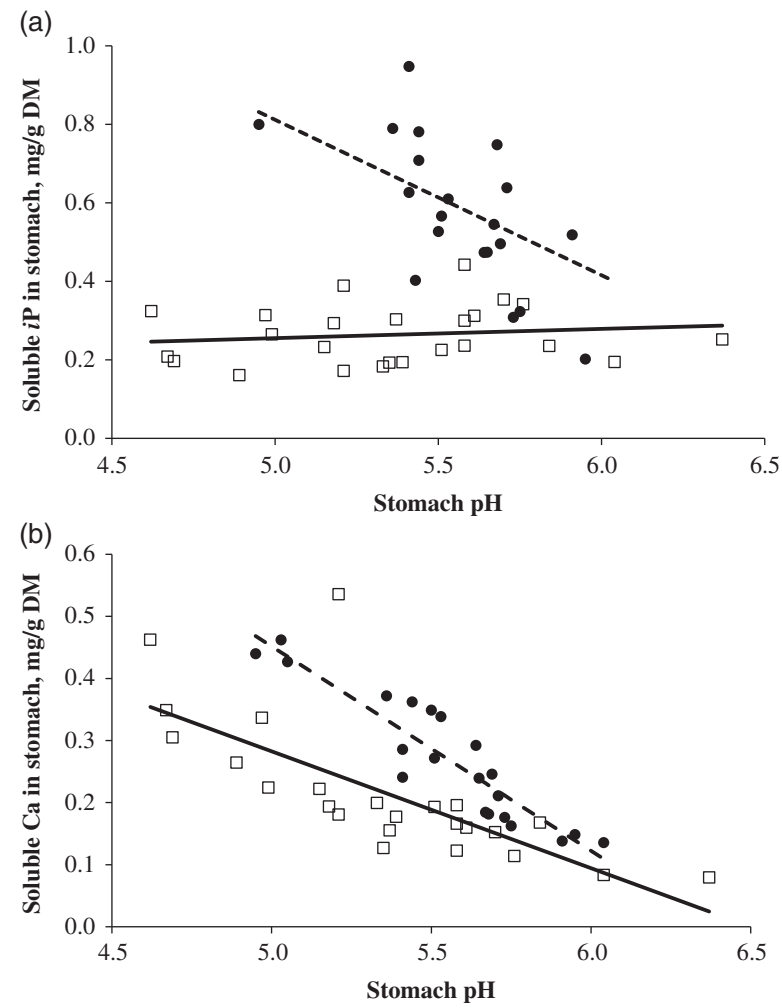

Figure 1 Relation between stomach $\mathrm{pH}$ and stomach solubility of $\mathrm{P}$ (a) and $\mathrm{Ca}$ (b) in pigs fed diets without microbial phytase ( $\square$ ) or with microbial phytase (๑). (a) Without microbial phytase: $y=0.139+0.027 x, \quad R^{2}=0.02, \quad P=0.52, \quad n=24 ;$ with microbial phytase: $\quad y=2.790-0.396 x, \quad R^{2}=0.31, \quad P=0.009, \quad n=20$. (b) Without microbial phytase: $y=1.223-0.188 x, R^{2}=0.53$, $P<0.001, \quad n=24$; with microbial phytase: $y=2.098-0.329 x$, $R^{2}=0.85, P<0.001, n=21$.

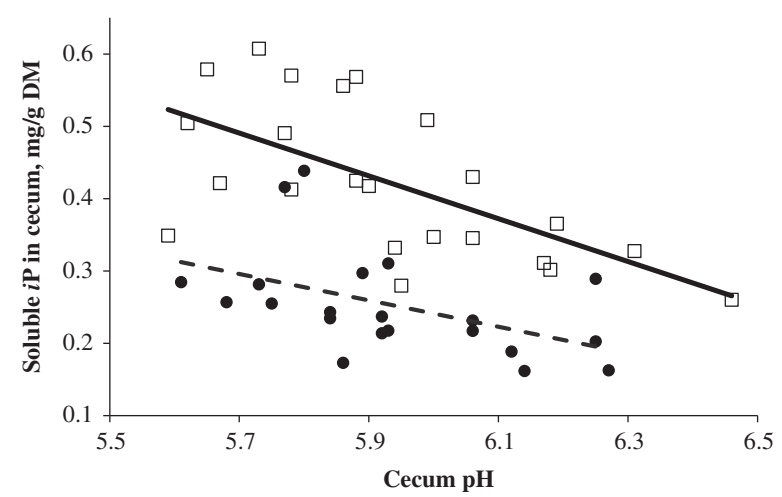

Figure 2 Relation between cecum $\mathrm{pH}$ and cecum solubility of $\mathrm{P}$ in pigs fed diets without microbial phytase $(\square)$ and with microbial phytase ( $(\mathbf{0})$. Without microbial phytase: $y=2.178-0.296 x, R^{2}=0.40, P<0.001$, $n=24$; with microbial phytase: $y=1.337-0.183 x, R^{2}=0.24$, $P=0.026, n=21$.

content in diets supplemented with microbial phytase was increased. These results can be explained by the higher $\mathrm{Ca}$ requirement to buffer the excess of acidity in the cecum with progressing fermentation as illustrated by Metzler-Zebeli et al. (2010) who reported a negative relationship between volatile fatty acids in feces and net post-ileal $\mathrm{Ca}$ absorption.
Microbial phytase significantly improved the ATTD of $P$ from $26.1 \%$ to $44.6 \%$. A similar improvement in the ATTD of $P$ from $28 \%$ to $56 \%$ was previously reported when phytase was added (863 FTU/kg) to a diet containing $13.2 \%$ canola meal (Akinmusire and Adeola, 2009). Microbial phytase supplementation led to an increase of $\mathrm{Ca}$ intake as dietary Ca level was adjusted using calcium carbonate in order to keep an equal Ca:apparent digestible $P$ ratio. However, microbial phytase had no impact on ATTD of Ca. This result is particularly surprising since microbial phytase is well known to improve Ca digestibility in canola meal as shown by GonzálezVega et al. (2013). However, in our experiment, calcium carbonate was added and its level was twice as high in diets supplemented with microbial phytase. According to GonzálezVega et al. (2015a), Ca from calcium carbonate is more easily bound to phytate, less soluble or less digestible than other sources which could explain the lack of significant effect of microbial phytase on ATTD of Ca. Calcium AR was significantly improved in pigs fed diets supplemented with microbial phytase $(45.2 \%$ v. $38.5 \%)$ with a reduction in urinary $\mathrm{Ca}$ (from $21 \%$ to $12 \%$ of the absorbed Ca). Microbial phytase also caused a large improvement of bone ash content, as previously reported in finishing pigs fed diets supplemented with $1000 \mathrm{FTU}$ of microbial phytase/kg which led to an 8 percentage units increase compared with unsupplemented diets (Varley et al., 2010). These observations are related to the greater availability of $P$ for bone mineralization and illustrate the close relationship between $\mathrm{P}$ and $\mathrm{Ca}$ at the metabolic level. Both minerals are deposited together in the skeleton to form hydroxyapatite crystals and the element in excess compared with the other is excreted in the urine (Létourneau-Montminy et al., 2010).

There was a strong negative relationship between stomach $\mathrm{pH}$ and $i \mathrm{P}$ solubility in pigs fed diets supplemented with microbial phytase. The presence of feed in the stomach induces distension, with a subsequent increase in intragastric pressure that stimulates acid secretion (Yen, 2001). The relatively acidic $\mathrm{pH}$ (5.45) is particularly favorable to phytate solubility and phytase activity (Yi and Kornegay, 1996). In consequence, a large amount of phosphate was released in this compartment. There was also a negative relationship between stomach $\mathrm{pH}$ and $\mathrm{Ca}$ solubility in pigs fed diets without or with microbial phytase. Maintenance of a low stomach $\mathrm{pH}$ may thus prevent the formation of Ca-phosphate complexes. Moreover, the higher level of provision of calcium carbonate in the diets supplemented with microbial phytase led to a higher buffering capacity of the feed $(129 \mathrm{v}$. 159). This caused a slight increase in $\mathrm{pH}$ of the stomach content $(5.36$ v. 5.54) which remained sufficiently low for optimal activity of microbial phytase which is between pH 2.5 and 5.5 (Dersjant-Li et al., 2015). Solubilization and hydrolysis processes occurring in the stomach proved to be limiting steps in P utilization (Kemme et al., 2006). This was supported by the positive relationship between iP solubility in the stomach and bone density as the skeleton is the main storage site of $P$ in the body (c.f. Supplementary Material). However, it is worthy to note that $\mathrm{pH}$ 
Rapeseed fiber and mineral digestibility

values in the stomach are higher than those generally found in the literature and must be taken with care. The $\delta$ between sampling and $\mathrm{pH}$ measurement may explain these results as a consequence of acid secretion disruption. Microbial phytase did not have any effect on the ileal recovery of $P$ while a significant decrease in cecal recovery occurred. These results suggest that part of the absorption of $P$ occurred in the cecum, which potentiates the effects of microbial phytase through the absorption of $P$ released by enzymes in the proximal part of the digestive tract. The small intestine is the major site of $P$ absorption (Breves and Schröder, 1991). The role of the large intestine in the regulation of $P$ absorption is more controversial. Some authors have reported secretion of $\mathrm{P}$ in the large intestine (Partridge, 1978a; Partridge et al., 1986), whereas others have reported significant absorption in both the cecum and the proximal colon (Liu et al., 2000). A significant decrease in the $\mathrm{pH}$ of the digestive content from the ileum to the cecum occurred (from 7.6 to 5.9), presumably due to volatile fatty acids production resulting from fiber fermentation. Results of previous studies showed a decrease in pH of 6.6 to 7.2 near the ileocecal junction to 5.7 to 6.8 in the cecum of pigs fed various wheat- or oat-based diets (Bach Knudsen and Hansen, 1991). Moreover, a strong negative relationship between the $\mathrm{pH}$ of the digesta of the cecum and the solubility of $i \mathrm{P}$ was found. The low $\mathrm{pH}$ in the large intestine might have resulted in the improvement of the solubility of $\mathrm{Ca}$ and phosphate, with a subsequent increase in their absorption (González-Vega et al., 2015b). It is of note that the solubility of both $\mathrm{P}$ and $\mathrm{Ca}$ in the cecum was extremely low (around 2.4\%). This could be attributed to the buffering functions of $\mathrm{Ca}$ and phosphate in order to compensate for the low pH. Indeed, $\mathrm{Ca}$ and phosphate have a major role for the buffering capacity throughout the intestinal lumen, forming insoluble complexes at $\mathrm{pH}$ values above 6 (Lawlor et al., 2005; Selle et al., 2009). The higher Ca intake in pigs fed diets with phytase caused an increase in the flow of Ca entering the large intestine, which might explain the higher $\mathrm{pH}$ of the digesta of the colon observed with microbial phytase.

In conclusion, the present findings indicate that dietary fiber content of RSM does not have a strong effect on digestive processes in the proximal part of the gastrointestinal tract of pigs. However, dehulling of RSM improved the availability of phytate and the phosphate released in the stomach. This study showed that the large intestine has a significant role in the absorption of $\mathrm{P}$ and potentiates the effect of microbial phytase due to its low $\mathrm{pH}$. Dietary fiber from rapeseed induces acidification of the cecal content, thereby improving iP solubility, which may improve its absorption.

\section{Acknowledgments}

The authors are grateful to MiXscience, Terres Inovia and Terres Univia for their financial support, M. Alix, A. Chauvin, F. Le Gouevec, C. Jaeger, R. Janvier, J. Liger and V. Piedvache for the animal care, Y. Jaguelin and A. Starck for their help with laboratory analysis and D. Gaudré for his expert advice on bone density results.

\section{Supplementary material}

To view supplementary material for this article, please visit https://doi.org/10.1017/S1751731117001343

\section{References}

Adhikari PA, Heo JM and Nyachoti CM 2015. True and standardized total tract phosphorus digestibility in canola meals from Brassica napus black and Brassica juncea yellow fed to growing pigs. Journal of Animal Science 93, 209-216.

Akinmusire AS and Adeola 0 2009. True digestibility of phosphorus in canola and soybean meals for growing pigs: influence of microbial phytase. Journal of Animal Science 87, 977-983.

Bach Knudsen KE and Hansen I 1991. Gastrointestinal implications in pigs of wheat and oat fractions - part 1. British Journal of Nutrition 65, 217-232.

Baye K, Guyot JP and Mouquet-River C 2015. The unresolved role of dietary fibers on mineral absorption. Critical Reviews in Food Science and Nutrition 57, 949-957.

Breves G and Schröder B 1991. Comparative aspects of gastrointestinal phosphorus metabolism. Nutrition Research Review 4, 125-140.

Carré $P$, Quinsac A, Citeau $M$ and Fine $F$ 2015. A re-examination of the technical feasibility and economic viability of rapeseed dehulling. Oilseeds \& Fats Crops and Lipids 22, D304.

Claye SS, Idouraine A and Weber CW 1998. In-vitro mineral binding capacity of five fiber sources and their insoluble components for magnesium and calcium. Food Chemistry 61, 333-338.

Den Hartog LA, Huisman J, Thielen WJG, Van Schayk GHA, Boer H and Van Weeden EJ 1988. The effect of including various structural polysaccharides in pig diets on ileal and faecal digestibility of amino acids and minerals. Livestock Production Science 18, 157-170.

Dersjant-Li Y, Awati A, Schulze H and Partridge G 2015. Phytase in non-ruminant animal nutrition: a critical review on phytase activities in the gastrointestinal tract and influencing factors. Journal of the Science of Food and Agriculture 95, 878-896.

Engelen AJ, van der Heeft FC, Randsdorp PHG and Smits ELC 1994. Simple and rapid determination of phytase activity. Journal of AOAC International 77, 760-764.

González-Vega JC, Walk CL, Liu Y and Stein HH 2013. Determination of endogenous intestinal losses of calcium and true total tract digestibility of calcium in canola meal fed to growing pigs. Journal of Animal Science 91, 4807-4816.

González-Vega JC, Walk CL and Stein HH 2015a. Effect of microbial phytase on apparent and standardized total tract digestibility of calcium in calcium supplements fed to growing pigs. Journal of Animal Science 93, 2255-2264.

González-Vega JC, Walk CL and Stein HH 2015b. Effect of phytate, microbial phytase, fiber, and soybean oil on calculated values for apparent and standardized total tract digestibility of calcium and apparent total tract digestibility of phosphorus in fish meal fed to growing pigs. Journal of Animal Science 93, 4808-4818.

Heijnen ML and Beynen A 1998. Effect of consumption of uncooked (RS2) and retrograded (RS3) resistant starch on apparent absorption of magnesium, calcium and phosphorus in pigs. European Journal of Nutrition 37, 13-17.

Jha $R$ and Berrosco JD 2015. Review: dietary fiber utilization and its effects on physiological functions and gut health in swine. Animal 9, 1441-1452.

Jondreville $C$ and Dourmad JY 2005. Le phosphore dans la nutrition des porcs. INRA Productions Animales 18, 183-192.

Kemme PA, Schlemmer U, Mroz Z and Jongbloed AW 2006. Monitoring the stepwise phytate degradation in the upper gastrointestinal tract of pigs. Journal of the Science of Food and Agriculture 86, 612-622.

Kerr BJ, Weber TE, Miller PS and Southern LL 2010. Effect of phytase on apparent total tract digestibility of phosphorus in corn-soybean meal diets fed to finishing pigs. Journal of Animal Science 88, 238-247.

Lawlor PG, Lynch PB, Caffrey PJ, O'Reill JJ and Connell MK 2005. Measurements of the acid-binding capacity of ingredients used in pigs diets. Irish Veterinary Journal 58, 447-452.

Létourneau-Montminy MP, Narcy A, Magnin M, Sauvant D, Bernier JF, Pomar C and Jondreville $C$ 2010. Effect of reduced dietary calcium concentration and phytase supplementation on calcium and phosphorus utilization in weanling pigs with modified mineral status. Journal of Animal Science 88, 1706-1717. 


\section{Bournazel, Lessire, Duclos, Magnin, Même, Peyronnet, Recoules, Quinsac, Labussière and Narcy}

Liu J, Bollinger DW, Ledoux DR and Venum TL 2000. Effects of dietary calcium: phosphorus ratios on apparent absorption of calcium and phosphorus in the small intestine, cecum, and colon of pigs. Journal of Animal Science 78, 106-109.

Metzler BU and Monsenthin R 2008. A review of Interactions between dietary fiber and the gastrointestinal microbiota and their consequences on intestina phosphorus metabolism in growing pigs. Asian-Australian Journal of Animal Science 21, 603-615.

Metzler-Zebeli BU, Hooda S, Mosenthin R, Gänzle MG and Zijlstra RT 2010 Bacterial fermentation affects net mineral flux in the large intestine of pigs fed diets with viscous and fermentable nonstarch polysaccharides. Journal of Animal Science 88, 3351-3362.

Nortey TN, Patience JF, Sands JS, Trottier NL and Zijlstra RT 2008. Effects of xylanase supplementation on the apparent digestibility and digestible content of energy, amino acids, phosphorus, and calcium in wheat and wheat by-products from dry milling fed to grower pig. Journal of Animal Science 86, 3450-3464.

Partridge IG 1978a. Studies on digestion and absorption in the intestines of growing pigs. 3. Net movements of mineral nutrients in the digestive tract. British Journal of Nutrition 39, 527-537.

Partridge IG 1978b. Studies on digestion and absorption in the intestines of growing pigs. Effect of dietary cellulose and sodium levels on mineral absorption. British Journal of Nutrition 39, 539-545.

Partridge IG, Simons $O$ and Bergner $H$ 1986. The effects of treated straw meal on ileal and faecal digestibility of nutrients in pigs. Archives of Animal Nutrition 36, 351-359.

Rousseau $X$, Valable AS, Létourneau-Montminy MP, Même N, Godet $E$, Magnin M, Nys Y, Duclos MJ and Narcy A 2016. Adaptive response of broilers to dietary phosphorus and calcium restrictions. Poultry Science 95, 1-12.
Sauvant D, Perez JM and Tran G 2004. Tables de composition et de valeur nutritive des matières premières destinées aux animaux d'élevage: porcs, volailles, bovins, ovins, caprins, lapins, chevaux, poissons. INRA Editions, Versailles, France.

Scholz-Arhens KE and Schrezenmeir J 2007. Inulin and oligofructose and mineral metabolism: the evidence from animal trials. The Journal of Nutrition 137 2513S-2523S.

Selle PH, Cowieson AJ and Ravindran V 2009. Consequences of calcium interactions with phytate and phytase for poultry and pigs. Livestock Science 124 126-141.

Shi C, He J, Yu B, Mao X, Zheng P, Huang Z and Chen D 2015. Amino acid, phosphorus and energy digestibility of Aspergillus niger fermented rapeseed meal fed to growing pigs. Journal of Animal Science 93, 2916-2925.

Singh PK 2008. Significance of phytic acid and supplemental phytase in chicken nutrition: a review. World's Poultry Science Journal 64, 553-580.

Van Soest PJ, Robertson JB and Lewis A 1991. Methods for dietary fiber, neutral detergent fiber, and nonstarch polysaccharides in relation to animal nutrition. Journal of Dairy Science 74, 3583-3597.

Varley PF, Lynch PB, Callan JJ and O'Doherty JV 2010. Effect of phytase concentration in a low phosphorus weaner pig diet and its subsequent effect on bone development in the finished pig. Livestock Science 134, 218-220.

Yen JT 2001. Anatomy of the digestive system and nutritional physiology. In Swine nutrition, 2nd edition (ed. AJ Lewis and LL Southern), pp. 31-57. CRC Press, Boca Raton, FL, USA.

Yi Z and Kornegay ET 1996. Sites of phytase activity in the gastrointestinal tract of young pigs. Animal Feed Science and Technology 61, 361-368. 